\title{
Effect of Number of Lactation Records on the Selection Rates in Holstein Dairy Cattle
}

\author{
Kwang-Hyun Cho ${ }^{1}$, Yun-Ho Choy ${ }^{1}$, Hong-Sik Kong ${ }^{2}$, Hak-Kyo Lee ${ }^{2}$, Sung-Hoon Kim ${ }^{2}$ and Kyung-Do Park ${ }^{2 *}$ \\ ${ }^{1}$ National Institute of Animal Science, RDA, Chungnam, 330-801, Korea \\ ${ }^{2}$ The Animal Genomics and Breeding Center, Hankyong National University, Anseong-si, Gyeonggi-do, 456-749, Korea
}

\begin{abstract}
This experiment was conducted to investigate the effects of lactation records in Holstein dairy cattle on the selection rates using a total of 341,436 test records from 113, 812 heads of cattle from first to third lactation. Heritabilities for milk, fat, and protein yields were highest at first lactation $(0.28,0.24$, and 0.27 , respectively), and decreased to $0.14,0.15$, and 0.13 at third lactation. For the milk yields, phenotypic correlations between first and second lactation, first and third lactation, and second and third lactation were low $(0.49,0.39$, and 0.47 , respectively), while genetic correlations among consecutive lactations and between second and third were above 0.8 and 0.9. In Model I, of the 1,138 heads the top $1 \%$ were selected based on first lactation records, only $32.4 \%$ (396 heads) were re-selected when the second lactation records were included and the $67.6 \%(769$ heads) were newly selected animals. While in Model II, $85.1 \%$ (1,138 heads) of the animals which were selected as the top $1 \%$ on the basis of first and second lactation records were included. A multiple trait evaluation method using multiple lactation records is more desirable than a single trait evaluation method using first lactation records only.
\end{abstract}

(Key words : Holstein, Lactation, Heritability, Selection rate, Genetic correlation)

\section{INTRODUCTION}

Since the year 1989 adoption as the dairy cattle evaluation method used by the United States Department of Agriculture (USDA), animal models based on BLUP theory have been one of the most efficient methods for evaluating dairy cattle worldwide.

In Korea, the National Dairy Herd Improvement(DHI) program was initiated by the National Agricultural Cooperative Federation (NACF) in year 1979. Under the DHI program, data regarding individual records on milk fat and protein yields, nutrition levels, somatic cell counts, mastitis and reproduction are collected and analyzed once a month with the help of co-operative members for more effective dairy management.

Since the introduction of the animal models, the genetic performance of dairy cattle has been evaluated by the single trait evaluation: the milk yield at first lactation (NIAS, 2011). To improve dairy cattle it is critical to precisely evaluate the genetic performance of individuals, and it is well established that for the evaluation of dairy cattle, more accurate information can be obtained when the lactation records after second lactation are used, as compared to first lactation records alone (Powell and Norman, 1981; Cassell and McDaniel, 1983).

It is essential to include first lactation records in the animal models, but the accuracy is decreased because selection effects due to temporary and permanent environmental effects are ignored, thus cows with higher milk yields at later lactations will not be selected if only evaluated using the first lactation records. Wiggans et al. (1988) also reported that this method is more realistic as it includes permanent environmental effects in the animal models.

Recently, in many countries, the application of multiple traits, multiple country genetic evaluation models for production yields are under active discussion (Nilforooshan et al., 2010). This experiment was conducted to investigate the effects of lactation records of dairy cattle on selection rates using two analysis models and to propose a new evaluation model.

* Corresponding author: Kyung-Do Park, The Animal Genomics and Breeding Center, Hankyong National University, Anseong-si, Gyeonggi-do, 456-749, Korea. Tel: +82-31-670-5656, Fax: +82-31-670-5657, E-mail: doobalo@hknu.ac.kr 


\section{MATERIALS AND METHODS}

\section{Data description}

A total of 1,461,043 test records were collected from cattle calved from year 1985 through 2010 at the Dairy Cattle Improvement Center and a total of 341,436 test records from 113,812 heads of cattle with first to third lactation were used.

Milk yields (milked twice a day) adjusted to a mature equivalent of 305 days, milk fat, and protein yields were analyzed. There were 3,439 herds and 46,459 herd-yearseason. Records from cattle whose herd-year-season were less than three were deleted. Average milk, fat and protein yields were $9,520 \mathrm{~kg}, 362 \mathrm{~kg}$ and $303 \mathrm{~kg}$ respectively, and the average number of months of calving ages at first, second and third parity were 26, 40 and 54 months, respectively (Table 1).

The number of animals used for the analysis was 145,492, of which 113,812 cattle had complete production records. The number of animals with records from both parents was $55,671(48.9 \%)$ and that of animals without records from either parent was 52,756(46.4\%), while the number of animals with records from only one parent was 5,376 (4.7\%). The number of sires was 971 (Table 2).

\section{Statistical methods}

The statistical models for estimating variance components and breeding values of production traits is as follows:

$$
\begin{aligned}
& \mathrm{y}=\mathrm{Xb}+\mathrm{Za}+\mathrm{Zp}+\mathrm{e} \cdots \cdot \text { Model I } \\
& \mathrm{y}=\mathrm{Xb}+\mathrm{Za}+\mathrm{e} \cdots \cdots \cdot \text { Model II }
\end{aligned}
$$

Where, $y=$ observation vector of ME305 days milk, fat and protein yields; $b=a$ vector of fixed herd-year-season effect; $a=a$ vector of random additive effect; $p=a$ vector of random permanent environmental effect; $\mathrm{X}, \mathrm{Z}=$ incident matrices for $\mathrm{b}$, $\mathrm{a}$, and $\mathrm{p}$; and $\mathrm{e}=$ vector of random residual effect.

$\operatorname{Var}(\mathrm{a})=\mathrm{A} \otimes \sigma_{\mathrm{a}}^{2}, \quad \operatorname{Var}(\mathrm{p})=\mathrm{I} \otimes \sigma_{\mathrm{p}}^{2}, \quad \operatorname{Var}(\mathrm{e})=\mathrm{I} \otimes \sigma_{\mathrm{e}}^{2}$, where, $\mathrm{A}$ $=$ numerator relationship matrix and $\mathrm{I}=$ identity matrix. Variance components and the breeding values of animals for production traits were estimated using the VCE and PEST programs, respectively (Groeneveld, 1990 Groeneveld et al. 2008).

\section{RESULTS AND DISCUSSION}

\section{Genetic parameters}

Variance components, heritabilities and repeatabilities for the adjusted milk, fat and protein yields are shown in Table 3 .

When the milk trait records for only the first lactation were used for analysis, the estimates of heritabilities for the milk, fat and protein yields were $0.29,0.25$ and 0.28, respectively.

Table 1. Number of records, mean and standard deviations (SD) for ME 305 days milk, fat and protein yields

\begin{tabular}{|c|c|c|c|c|c|c|}
\hline \multirow{2}{*}{ Lactation } & \multirow{2}{*}{ No. of records } & \multirow{2}{*}{$\begin{array}{c}\text { Milk } \\
\text { Mean } \pm \text { STD }\end{array}$} & \multirow{2}{*}{$\begin{array}{c}\text { Fat } \\
\text { Mean } \pm \text { STD }\end{array}$} & \multirow{2}{*}{$\begin{array}{c}\text { Protein } \\
\text { Mean } \pm \text { STD } \\
\end{array}$} & \multicolumn{2}{|c|}{ Month of calving age } \\
\hline & & & & & Mean & Mode \\
\hline 1 & 113,812 & $8806 \pm 1687$ & $341 \pm 68$ & $283 \pm 52$ & 26 & 24 \\
\hline 2 & 113,812 & $9791 \pm 1907$ & $371 \pm 75$ & $313 \pm 58$ & 40 & 36 \\
\hline 3 & 113,812 & $9962 \pm 1990$ & $375 \pm 77$ & $312 \pm 60$ & 54 & 50 \\
\hline Overall & 341,436 & $9520 \pm 1934$ & $362 \pm 75$ & $303 \pm 59$ & - & - \\
\hline
\end{tabular}
(kg) by parity

Table 2. Pedigree informations of the data

\begin{tabular}{lrrcc}
\hline \multicolumn{1}{c}{ Progeny group } & No. of records (\%) & No. of cows (\%) & No. of sires & No. of dams \\
\hline \hline Known both parents & $167,013(48.9)$ & $55,671(48.9)$ & 952 & 47,425 \\
only sire & $7,512(2.2)$ & $2,504(2.2)$ & 418 & - \\
only dam & $8,616(2.5)$ & $2,872(2.5)$ & - & 2,820 \\
Unknown parents & $158,295(46.4)$ & $52,765(46.4)$ & - & - \\
Overall $^{1)}$ & 341,436 & 113,812 & 971 & 49,738 \\
\hline
\end{tabular}

${ }^{1)}$ Total number of sires and dams used across all data (not the column sum). 
Table 3. Additive $\left(\sigma_{a}^{2}\right)$, permanent environmental $\left(\sigma_{p e}^{2}\right)$, residual $\left(\sigma_{e}^{2}\right)$ variance components, genetic and phenotypic correlations, heritabilities $\left(\mathrm{h}^{2}\right)$ and repeatabilities $(r)$ for ME 305 days milk, fat and protein yields $(\mathrm{kg})$

\begin{tabular}{|c|c|c|c|c|c|c|c|c|c|}
\hline \multirow{2}{*}{ Lactation } & \multirow{2}{*}{ Traits } & \multicolumn{3}{|c|}{ Variance components } & \multicolumn{3}{|c|}{ Correlations $^{1)}$} & \multirow{2}{*}{$h^{2}$} & \multirow{2}{*}{$\mathrm{r}$} \\
\hline & & $\sigma_{a}^{2}$ & $\sigma_{\mathrm{pe}}^{2}$ & $\sigma_{\mathrm{e}}^{2}$ & 1 & 2 & 3 & & \\
\hline \multirow[t]{3}{*}{$1^{\text {st }}$} & (1) Milk & 503103 & - & 1225719 & & 0.68 & 0.91 & $0.29 \pm 0.02$ & - \\
\hline & (2) Fat & 624 & - & 1895 & 0.58 & & 0.76 & $0.25 \pm 0.02$ & - \\
\hline & (3) Protein & 426 & - & 1103 & 0.85 & 0.74 & & $0.28 \pm 0.02$ & - \\
\hline \multirow[t]{3}{*}{$1^{\text {st }}-2^{\text {nd }}$} & (1) Milk & 551960 & 410428 & 1253698 & & 0.71 & 0.92 & $0.25 \pm 0.01$ & 0.43 \\
\hline & (2) Fat & 717 & 645 & 1710 & 0.60 & & 0.78 & $0.23 \pm 0.01$ & 0.44 \\
\hline & (3) Protein & 485 & 340 & 1122 & 0.86 & 0.77 & & $0.25 \pm 0.01$ & 0.42 \\
\hline \multirow[t]{3}{*}{$1^{\text {st }}-3^{\text {rd }}$} & (1) Milk & 558747 & 518338 & 1360386 & & 0.72 & 0.92 & $0.23 \pm 0.01$ & 0.44 \\
\hline & (2) Fat & 712 & 728 & 1914 & 0.58 & & 0.79 & $0.21 \pm 0.01$ & 0.43 \\
\hline & (3) Protein & 402 & 460 & 1222 & 0.83 & 0.75 & & $0.19 \pm 0.01$ & 0.41 \\
\hline
\end{tabular}

${ }^{1)}$ Upper triangle: phenotypic correlation, lower triangle: genetic correlation.

When the milk trait records from the first and second lactation were used for analysis, the estimates of heritabilities for the milk, fat and protein yields were $0.25,0.23$ and 0.25 , respectively, and when the milk trait records from first, second and third lactation were used for analysis, the estimates of heritabilities for the milk, fat and protein yields were $0.23,0.21$ and 0.19 , respectively.

With more lactation records the estimates of heritabilities for the milk traits collectively decreased. The estimates of repeatabilities for the milk, fat and protein yields ranged from 0.41 to 0.44 . The genetic correlation for the milk and fat yields, milk and protein yields, and fat and protein yields estimated from the first lactation records were $0.58,0.85$ and 0.74 , respectively. The genetic correlation for the milk and fat yields, milk and protein yields, and fat and protein yields estimated from first, second and third lactation records were $0.58,0.83$ and 0.75 , respectively, which was similar to estimates from the first lactation records.

Heritabilities, genetic and phenotypic correlations estimated using Model II is shown in Table 4. Heritabilities for milk yields, milk fat and protein yields were highest at the first lactation ( $0.28,0.24$ and 0.27 , respectively), but decreased to $0.14,0.15$ and 0.13 at the third lactation. These are similar results to those of previous reports (Powell and Norman, 1981; Montaldo et al., 2010).

For the milk yields, phenotypic correlations between the first and second lactation, the first and third lactation and the second and third lactation were low $(0.49,0.39$ and 0.47 , respectively), while genetic correlations among consecutive lactations and between the second and third lactation were above 0.8 and 0.9 . The same trends were noted in milk fat and protein yields, which suggested that for the milk yields, environment effects increased in later lactations.

\section{Selection rates of cows}

To estimate the breeding values of cows in animal models I and II, the ioc method from the PEST program was used and the convergence criteria was $10^{-4}$. It took 5,000 rounds for the conversion. Cattle were ranked by their breeding value for milk traits and the selection rate changes to the top $1 \%$ and $5 \%$ are presented in Tables 5 and 6 .

Table 4. Heritabilities, genetic and phenotypic correlations among lactations in each trait

\begin{tabular}{|c|c|c|c|c|c|c|c|c|c|}
\hline \multirow{2}{*}{ Lactation } & \multicolumn{3}{|c|}{ Milk } & \multicolumn{3}{|c|}{ Fat } & \multicolumn{3}{|c|}{ Protein } \\
\hline & 1 & 2 & 3 & 1 & 2 & 3 & 1 & 2 & 3 \\
\hline 1st (1) & $0.28^{*}$ & 0.49 & 0.39 & $0.24 *$ & 0.48 & 0.38 & $0.27^{*}$ & 0.48 & 0.36 \\
\hline 2nd (2) & 0.89 & $0.18^{*}$ & 0.47 & 0.92 & $0.18^{*}$ & 0.46 & 0.85 & $0.17^{*}$ & 0.47 \\
\hline 3rd (3) & 0.85 & 0.98 & $0.14^{*}$ & 0.89 & 0.95 & $0.15^{*}$ & 0.81 & 0.97 & $0.13^{*}$ \\
\hline
\end{tabular}

* Diagonal: heritability, upper triangle: phenotypic correlation, lower triangle: genetic correlation. 
Cho et al. ; Effect of Lactation Records on the Selection Rates

Table 5. Percentage of the changes in the selection of elite cattle according to the number of parity records (top $1 \%=1138,5 \%=5690$ ) using Model I

\begin{tabular}{|c|c|c|c|c|c|c|}
\hline \multirow{2}{*}{ Traits } & \multicolumn{3}{|c|}{ Top 1\% } & \multicolumn{3}{|c|}{ Top 5\% } \\
\hline & $1^{\text {st }}$ & $1^{\text {st }} \sim 2^{\text {nd }}$ & $1^{\text {st }} \sim 3^{\text {rd }}$ & $1^{\text {st }}$ & $1^{\text {st }} \sim 2^{\text {nd }}$ & $1^{\text {st }} \sim 3^{\text {rd }}$ \\
\hline Milk & $100.0(0.0)$ & $32.4(67.6)$ & $20.3(79.7)$ & $100.0(0.0)$ & $43.1(56.9)$ & $32.2(67.8)$ \\
\hline Fat & $100.0(0.0)$ & $34.7(65.3)$ & $25.6(74.4)$ & $100.0(0.0)$ & $44.0(56.0)$ & $34.2(65.8)$ \\
\hline Protein & $100.0(0.0)$ & $34.1(65.9)$ & $24.8(75.2)$ & $100.0(0.0)$ & $43.0(57.0)$ & $35.1(64.9)$ \\
\hline
\end{tabular}

Percentage $(\%)$ of new elite cows.

Table 6 . Percentage of the changes in selection of elite cattle according to the number of parity records (top $1 \%$ $=1138,5 \%=5690$ ) using Model II

\begin{tabular}{|c|c|c|c|c|c|c|}
\hline \multirow{2}{*}{ Traits } & \multicolumn{3}{|c|}{ Top 1\% } & \multicolumn{3}{|c|}{ Top 5\% } \\
\hline & $1^{\text {st }}$ & $1^{\text {st }} \sim 2^{\text {nd }}$ & $1^{\text {st }} \sim 3^{\text {rd }}$ & $1^{\mathrm{st}}$ & $1^{\text {st }} \sim 2^{\text {nd }}$ & $1^{\text {st }} \sim 3^{\text {rd }}$ \\
\hline Milk & $100.0(0.0)$ & $85.1(14.9)$ & $77.0(23.0)$ & $100.0(0.0)$ & $88.8(11.2)$ & 83.4 (16.6) \\
\hline Fat & $100.0(0.0)$ & $87.3(12.7)$ & $81.6(18.4)$ & $100.0(0.0)$ & $89.2(10.8)$ & $84.6(15.4)$ \\
\hline Protein & $100.0(0.0)$ & $82.1(17.9)$ & $73.7(26.3)$ & $100.0(0.0)$ & $85.5(14.5)$ & $79.2(20.8)$ \\
\hline
\end{tabular}

Percentage $(\%)$ of new elite cows.

In the 1,138 heads of cattle, of the top $1 \%$ selected on the basis of the first lactation records alone, only $32.4 \%$ (396 heads) were selected when the second lactation records were included in the selection model, and 67.6\% (769 heads) of the new top $1 \%$ were newly selected animals. When the third lactation records were included, only $20.3 \%$ (231 heads) of the original top $1 \%$ cows were selected (Table 5).

Therefore, it is very clear that the second lactation records are the most effective for the ranking of cows and similar trends were noted in milk fat and protein yields.

Heritability estimates for milk yields from the first lactation was 0.29 . Therefore, when the heritability for milk yields estimated from the first three lactation records is calculated as 0.23 , records from the first lactation will be under-estimated and those from the third lactation will be over-estimated. To address these problems, multiple traits evaluation of lactations was proposed (Muir et al., 2007; Hammami et al., 2008; Miglior et al. 2009). When the milk yields were evaluated using Model II, the average breeding value of traits from first to third lactation is taken into account.

When ranked using the average breeding value of the first and second lactations, $85.1 \%(1,138$ heads $)$ of the animals which were selected for the top $1 \%$ on the basis of first lactation were included and when the third lactation records are included to the selection model $77.0 \%$ (876 heads) were included. Similar results were seen in milk and protein yields.

Clearly the production records of the first lactation are the most important for estimating breeding values.

First lactation records are available sooner on more cows and are less susceptible to error from selection, injury, previous days dry and mastitis than are later lactation records. However, first lactation records have been considerably less accurate in predicting lifetime performance traits. The third lactation was the most highly related to lifetime production of female offspring. Later lactation records provide additional information for more accurate sire and cow evaluations.

The economic importance of later lactation records compared to first is that more records can be obtained and actual yields will increase in later lactations. Later lactation records may contain useful information on the lifetime profitability of the sire progeny groups.

\section{CONCLUSION}

A multiple traits evaluation method using multiple lactation records is more desirable than a single trait evaluation method using first lactation records only. However, further studies on the economic weight by parity are needed. 


\section{ACKNOWLEDGEMENTS}

This work was carried out with the support of "Cooperative Research Program for Agriculture Science and Technology Development (Project No. PJ907160)" Rural Development Administration, Republic of Korea.

\section{REFERENCES}

Cassell, B. G. and McDaniel, B. T. 1983. Use of later records in dairy sire evaluation: a review. J. Dairy Sci. 66:1-10.

Genetic Evaluation Reports of Dairy Cattle in Korea. 2011. National Institute of Animal Science (NIAS), RDA, Korea.

Groeneveld, E. 1990. PEST User's Manual. Institute of Animal Husbandry and Animal Behaviour, Federal Agricultural Research Centre (FAL), Germany.

Groeneveld, E., Kovac, M. and Mielenz, N. 2008. VCE User's Guide and Reference Manual Version 6.0. Institute of Farm Animal Genetics, Friedrich Loeffler Institute (FLI), Germany.

Hammami, H., Rekik, B., Soyeurt, H., Ben Gara, A. and Gengler, N. 2008. Genetic Parameters for Tunisian Holsteins Using a Test-Day Random Regression Model. J. Dairy Sci. 91: 2118-2126.

Miglior, F., Gong, W., Wang, Y., Kistemaker, G. J., Sewalem, A. and Jamrozik, J. 2009. Short communication: Genetic parameters of production traits in Chinese Holsteins using a random regression test-day model. J. Dairy Sci. 92:4697706.

Montaldo, H. H, Castillo-Juarez, H., Valencia-Posadas, M., Cienfuegos-Rivas, E. G. and Ruiz-Lopez. F. J. 2010. Genetic and environmental parameters for milk production, udder health, and fertility traits in Mexican Holstein cows. J. Dairy Sci. 93:2168-2175.

Muir, B. L., Kistemaker, G., Jamrozik, J. and Canavesi, F. 2007. Genetic Parameters for a Multiple-Trait Multiple-Lactation Random Regression Test-Day Model in Italian Holsteins. J. Dairy Sci. 90:1564-1574.

Nilforooshan, M. A., Jakobsen, J. H., Fikse, W. F., Berglund, B. and Jorjani, H. 2010. Application of a multiple traits, multiple country genetic evaluation model for female fertility traits. J. Dairy Sci. 93:5977-5986.

Powell, R. L. and Norman, H. D. 1981. Different lactations for estimating genetic merit of dairy cows. J. Dairy Sci. 64:321330.

Wiggans, G. R., Misztal, I. and Van Vleck, L. D. 1988. Animal model evaluation of Aryshire milk yield with all lactations, herdsire interaction, and groups based on unknown parents. J. Dairy Sci. 71:1319-1329

Wiggans, G. R. and Van Raden, P. M. 1989. USDA-DHIA animal model genetic evaluations. Natl. Coop. DHI program Handbook, Fact Sheet H-2, Washington, DC.

(Received Jul. 12, 2012; Revised Nov. 17, 2012; Accepted Feb. 20, 2013) 